\title{
Scientific Approach with Problem Posing Integrated in Introductory Microeconomics Theory, whether Work?
}

\author{
Albrian Fiky PRAKOSO ${ }^{1}$, Dhiah FITRAYATI ${ }^{2}$, Retno Mustika DEWI ${ }^{3}$
}

\begin{tabular}{l} 
ARTICLE INFO \\
\hline Article History: \\
Received 20.12.2017 \\
Received in revised form \\
13.02.2018 \\
Accepted \\
Available online 01.10 .2018
\end{tabular}

\begin{abstract}
This study aims to improve student learning outcomes in the introductory mic roeconomics theory subject. This research is included in classroom action research with three cycles. The model is use a scientific approach integrated with problem posing and was conducted on business education student Class A Universitas Negeri Surabay a. This learning model required the students to create a problem. When the students create a problem, they also think about the answer. This stage will make the students thinking twice. The students understanding will increase and have positive impact on improving student learning outcomes by those activity. This paper provides a new view to collaborate between a scientific approach integrated with problem posing to improve student learning outcomes.
\end{abstract}

(C) 2018 IJERE. All rights resenved

Keywords:

Scientific Approach, Problem Posing, Microeconomics.

\section{INTRODUCTION}

Education both at school and in college now required to lead to the Curriculum 2013, which refers to the Indonesian National Qualifications Framework (In Indonesia called KKNI). The Legislation and regulation of the curriculum of $2013 \mathrm{w}$ as passed, but most of the institutions do not apply.

In the other hand, the phenomenon that occurs when many students who have passed certain courses, but student proficiency level should not control what they could do based on the level that existed at KKNI. This is because at some universities is not currently implementing the curriculum in 2013.

Department of Economic Education Universitas Negeri Surabaya (Unesa) not currently applied curriculum 2013. Although in some departments in the Faculty of Economics has been implementing the curriculum in 2013, but the education department is still going to implement it.

It is necessary for their research on economic education majors related to the curriculum, 2013. One of the approaches used in the implementation of the curriculum 2013 is a scientific approach.

Based on information from several lecture in the Department of Economics, micro-economic subjects has always been a scourge for students. When they hear the word "micro" they always felt taboo. This is because in the course of micro contains many curves. For students, the curve is a difficult thing to understand. So most of the students have a sense of anti against introductory courses microeconomic theory especially when the material containing the curve.

This phenomenon is also supported by the pretest was conducted by researchers. Pretest was conducted by researchers as much as eight times. This is done because in the major forces Unesa economic education there are eight classes. The pretest was done very surprising. Most of the class 1st Semester had a value below 60. How ever, the class that has the low est value is Business Education class "A".

After further observation it turned out most of the Business Education class "A" students coming from vocational or high school science majors and only a small proportion coming from high school social studies department. While, this further to the information that Business Education class "A" has less knowledge about the introductory microeconomics theory subject.

In addition to the educational background of students Business Education class " $\mathrm{A}$ " is the cause of the low value of microeconomic theory this class is low, there are also other factors that influence it. The amount of material in the course Introduction to the Theory Microeconomics also be a cause of low student results Business Education class " $\mathrm{A}$ ". In the course students are required to memorize a lot of material, not to

Corresponding e-mail: albrianprakoso@unesa.ac.id Universitas Negeri Surabaya1,orcid.org/0000-0002-7594-0924

Universitas Negeri Surabaya ${ }^{2}$ orcid.org/0000-0001-8888-2738, Universitas Negeri Surabaya ${ }^{3}$ orcid.org/0000-0002-9464-0513 
Prakoso,A.F., Fitrayati,D., Dewi,R.M. (2018). Scientific approach with problem posing integ rated in introductory microeconomics theory, whether work? International Journal of Educational Research Review, 3 (4),1-10.

mention other courses totaling about 8 courses in one semester. It is becoming a heavy burden for students, so it needs to be given to the application of learning models that class.

After knowing there is a problem in Business Education class " $\mathrm{A}$ ", then in the class need to research based pertaining to the model, method, or approach to learning. With the implementation of the model, method, or approach to learning, the expected learning outcomes Business Education class " $\mathrm{A}$ " will increase.

The approach is applied to the curriculum in 2013 mentioned earlier. The approach is a scientific approach, but the scientific approach just considered insufficient to improve student results. It is necessary for the integration between scientific with such a method. The method was warmly discussed today is the method of filing a problem or commonly called the problem posing.

Solving method that is commonly used is the Problem Posing. Since many researchers argue that this method has been frequently used in research in this study tries to apply the problem posing method was rarely used in college at the same time combined with a scientific approach.

With the implementation of problem posing method, students are asked to submit a problem or issue and then also answer concerns or issues they have made. By creating problems or issues then indirectly the students will think of the answer as well. Thus the students will think twice, when they pose a problem or issue and then the second one is when they answer. In other hand, this research not only evaluate teh student, but also Lecturer like the research of Bahçuvanoğlu (2018) who evaluate Teachers Views Concerning Ideality Levels. But in this research will evaluate the lecturer activity aim be better.

Their integrated of scientific approach and problem posing method, students are expected to have a sharper memory about the course material which they have earned. Using two method was doing by Oladele (2017) who include norm-referenced methods and the criterion- referenced methods. In Addition, Ristanto, Zubaidah, Amin, and Rohman (2018) use Cooperative Integrated Reading and Composition in Biology Learning at Higher Education. So that is expected in this research is the application of a integrating between the scientific approach to problem posing method, the results of student learning in the Business Education class "A" 1 st semester introductory course microeconomic theory can be increased.

\section{Scientific Approach}

Scientific method was first introduced to the science of American education in the 19th century, as the emphasis on formalistic laboratory methods that lead to scientific facts (Hodson, 1996; Rudolph, 2005). The scientific method has the characteristics of "doing science". This method allows teachers or curriculum developers to improve the learning process, namely by breaking the process down into steps or stages in detail which contains instructions for the students carry out learning activities (Varelas and Ford, 2008). It is the basis of curriculum development in 2013 in Indonesia.

In the 2013 curriculum emphasizes on modern pedagogic dimension in learning, using a scientific approach (Ministry of Education and Culture 2013). The scientific approach in the learning stages will be outlined as follows: Observe Ask, Reasoning, Try, and Network Form.

\section{Problem Posing}

According Thobroni and Mustofa (2012) in principle problem posing learning model is a model of learning which require the students to ask questions about themselves through learning (training matter) independently. The application of problem posing learning model are as follows: 1) Lecturers explain the subject matter to the students. The use of props to clarify the concept is strongly recommended;2) Lecturers give exercises to taste; 3 ) Learners are asked to submit one or two pieces of matter that is challenging, and other learners should be able to finish. This task can also be done in groups; 4) at the next meeting at random, Lecturer asking the students to present their findings to the class question. In this case, the lecturer can determine the students selectively based on weight problems posed by learners; 5) Lecturers give homew ork individually.

\section{Integrating Scientific Approach with Problem Posing Method}


Prakoso,A.F., Fitrayati,D., Dewi,R.M. (2018). Scientific approach with problem posing integ rated in introductory microeconomics theory, whether work? International Journal of Educational Research Review, 3 (4),1-10.

Alloys Scientific Approach to the Problem Posing method can be detailed as follows: 1) In the first stage of observing the Scientific Approach combined with the first phase Problem Posing method, namely when the lecturer explained the subject matter to the students. The use of props to clarify the concept is strongly recommended; 2) In the second stage of Scientific approach is to ask, combined with the second stage of Problem Posing method which provides exercises Lecturer taste; 3) In the third phase approach, namely reasoning combined with the third stage of Problem Posing methods that Learners asked to submit one or two pieces of matter that is challenging, and other learners should be able to finish. This task can also be done in groups; 4 ) in the fourth stage that tries combined with the fourth stage of the method Problem Posing At the next meeting randomized is lecturer asked the students to present their findings to the class question. In this case, the lecturer can determine the students selectively based on weight problems posed by learners; 5) in the last stage of forming networks combined with last stage Problem Posing methods that lecturers give homew ork individually.

\section{Empirical study}

This article refers to several studies that have been done. First, by Japa (2014) stated that compared to conventional learning models, learning models of quantum -oriented open problem solving in mathematics it will produce better outcomes in basic thinking skills, critical thinking skills and creative thinking skills of students.

Second, collaborative research Lee, Lau, and Yip (2016) has reported the report on the design and evaluation of an inter-university collaborative project. Addition, collaborative professional development (Holmqvist, 2017; Wood, 2017) and lesson study collaboration (Skott and Møller, 2017). The difference of this research is to collaborate between scientific with problem posing.

Third, developing problem-solving by Bradshaw and Hazell (2017). In this research not used problem solving but problem posing which integrated with scientific approach.

Fourth, research that has been done by Fauziah, Abdullah, and Hakim (2013) resulted in learning materials based scientific approach through a model of problem-based learning, and received positive feedback from teachers and learners, so a positive impact on the increase of hard and soft skills of learners.

\section{METHOD}

The study design, include activities preparation learning materials conducted by researchers. Implementation research is the implementation phase of the learning materials has been prepared. Along with the implementation of learning, observers observe the activities undertaken Lecturers and Students. In carrying out the implementation of learning, researchers have prepared guidelines for observation instruments and provided for the observer.

Reflection is the final stage of each cycle. At this stage, researchers and observers gathered to discuss the data obtained in the study that has been done. If in the implementation of learning acquired data or records are deficient in the learning process so that phase should be done by researcher re planning to produce a new plan and are ready to be implemented in the next cycle.

\section{Data collection technique}

As for how the collection of such data can be briefly described as follows: (1) Research collected by student achievement test that requires answers to student results that include product ratings and affective when applied to the learning process Scientific Approach to Problem Posing method. In using assessment, provides researchers affective assessment sheets that are used to assess students in the field of behavior and attitudes during the learning process carried out by the researcher. In using the product or model assessment tests, researchers used the instrument in the form of a set of test questions; (2) Observation is used to collect data on the activities of lecturers and students during the learning activities that will be observed Lecturer grade and colleagues (observer).

\section{Research Instruments}


Prakoso,A.F., Fitray ati,D., Dewi,R.M. (2018). Scientific approach with problem posing integ rated in introductory microeconomics theory, whether work? International Journal of Educational Research Review, 3 (4),1-10.

The instrument used in this study are (1) Observation sheet Lecturer activity during the learning process; (2) Observation sheet Student activity during the learning process; (3) Sheet test to determine their knowledge and understanding of students before and after the application of Scientific Approach to the Problem method Posing.

\section{Data analysis}

The data obtained in this study will be analyzed using quantitative descriptive analysis method. At this stage of the learning management analysis, the data obtained from the observation sheet learning in the classroom that has been filled by an observer who is used to analyze the enforceability of learning by using models Scientific Approach and Problem Posing. Analyses were performed by interpreting the numeric values in sentences that are qualitative scale to determine its appropriateness.

The next analysis is Student Learning Outcomes. Data form the cognitive learning achievement test score. Before being used as a research instrument, those items should be tested prior to the class other than the class that will be used in research. Classes are used as a test instrument is Accounting Education class 1st semester, where the state of heterogeneous students and almost equal to the grade used in this study. This step is taken to determine the validity and reliability of the matter. Finally is analysis of student activities. Data observation of student activity during learning activities take place can be analyzed by a percentage (\%) of each activity by Riduw an (2009).

\section{Indicators of success}

In the context of this study, the success of the study can be seen from several indicators, namely: (1) The ability of the management class by the lecturer during the learning Scientific Approach to the Problem Posing method lasts $\geq 85 \%$; (2) The active participation by students during the learning Scientific Approach to the Problem Posing method taking place, that $\geq 85 \%$ of the number of students in attendance; (3) The results of study after the implementation approaches and methods Scientific Problem posing achieve mastery classical learning in $80 \%$ of the number of students who received grades or $\geq 70$ learning outcomes.

\section{FINDINGS}

The first step before taking Validity of research data is a matter that is used by researchers to determine student results against indicators or learning objectives through the instruments matter.

Exposure analysis of items that have been conducted by researchers, the researchers used questions that have met the criteria for each analysis items as detailed below.

Table 1. Conclusions Results Analysis of Grain Problem

\begin{tabular}{cc}
\hline Problem is invalid & Questions used in the study \\
\hline $2,3,18,32,35$ & $1,4,5,6,7,8,9,10,11,12,13,14,15,16,17,19,21,22,23,24,25,26,27,28,29$, \\
& $30,31,33,34,36,37,38,39,40,41,42,43,44,45,46,47,48,49,50$ \\
\hline$\Sigma=5$ & $\Sigma=45$ \\
\hline
\end{tabular}

Thus obtained questions used in this study as many as 45 . Of these 45 questions used in three cycles, where each cycle there are 15 questions.

Result study of cycle one, obtained lecturer activity that is part of the activity data Lecturer in implementing the learning process by using a Scientific Approach to the Problem Posing method. Implementation of new lecturers assessed by an observer through observation sheets, of these observations obtained data showing the ability of lecturers in teaching and learning.

Lecturer activity shows Rated $72 \%$. This value is derived from an assessment of the measures implementing learning activities by using a Scientific Approach to the Problem Posing method.

Based on the success criteria value of $72 \%$ on activity Lecturer in cycle 1 can be categorized either. Although even so, the value is still far from an indicator of success in this study. In the 
Prakoso,A.F., Fitrayati,D., Dewi,R.M. (2018). Scientific approach with problem posing integ rated in introductory microeconomics theory, whether work? International Journal of Educational Research Review, 3 (4),1-10.

implementation of learning in cycle 1 is a low value given by observers on the ability Lecturer in doing Final Problem Posing and motivation. Deficiencies in the activity Lecturer in cycle 1 is expected to be fixed in a cycle 2 .

The observation of student activities at the end of cycle 1 obtained value by $65 \%$. Although the value is relatively active but the value is still far to the success criteria of research that is equal to $85 \%$ of the number of students in attendance. Aspects that have low values is an aspect to 2,5,7,8,10, and 12 so that still needs to be enhanced significantly in the second cycle.

In terms of student results in cycle 1, the focus is on the cognitive learning. Once the researchers conducted an analysis items then researchers used the instrument to determine student learning outcomes. Improved student learning outcomes in the application of the method Scientific Approach Problem Posing can be seen through the test given each end of the cycle. On the implementation of the test, the number of questions in each cycle is 15 multiple choice questions. Based on data obtained in cycle 1 Student learning outcomes is still need for improvement, this can be proved by the results of calculations in the classical completeness, in cycle 1 only $61.7 \%$ classical completeness. This is an indicator of success in classical completeness $80 \%$ of students in attendance.

Further to observations ability Lecturer in applying the Scientific Approach to the method Problem Posing on the second cycle of the observer value obtained by value $75 \%$. Based on the success criteria value of $75 \%$ on activity Lecturer in cycle 2 can be considered good. Although there were increased from cycle 1 , but the value is still far from an indicator of success in this study. In the implementation of learning in cycle 2 is a low value given by observers on the ability Lecturer at the stage of observing, performing Problem Posing and motivation end.

Student activity observation results in cycle 2 obtained a final value of $76.6 \%$ is also quite active and still not meet the criteria for the success of research that is equal to $85 \%$ of the number of students in attendance. The value of the lowest aspect begins to turn into at the time of observing and apperception stage, so it needs to be increased again in the third cycle.

Student Learning Outcomes in Cycle 2 is already increase, this can be proved by the calculation of completeness in the classical, classical completeness in cycle 1 that was originally only $65.2 \%$ while in the second cycle increased to $73.5 \%$. This is an indicator of success in classical completeness $80 \%$ of students in attendance. So it is still need for improvement in cycle 3.

Activities Lecturer in Cycle 3 is fixed through the reflection of cycle 2 which is at the stage of observing and apperception. Based on the observations made by the observers showed a value of $92.3 \%$ is classified Excellent on all components. Because the data Lecturer activity has reached $92.3 \%$, then it meets the indicators of success of the research that is equal to $85 \%$ so that the cycle was stopped at 3 cycles.

Activities Students in Cycle 3 obtained a final value of 91.6\%, as very active and have met the success criteria of research that is equal to $85 \%$ of the number of students in attendance, so the cycle is stopped in Cycle 3.

And thelatter is the result of learning of students in Cycle 3 which has increased very significantly, this can be proved by the results of calculations in classical completeness in cycle 3 of $82.3 \%$. This is an indicator of success in classical completeness $80 \%$ of students in attendance. The cycle can be stopped at the third cycle.

\section{RESULT, DISCUSSION, AND SUGGESTIONS}

The success of a lesson in the college will be determined by the management of lecturers in teaching and learning. Based on observations of learning the course Introduction to the basic competence of microeconomic theory to analyze supply and demand using a Scientific Approach to the method of Problem Posing carried out at every stage well. 
Prakoso,A.F., Fitrayati,D., Dewi,R.M. (2018). Scientific approach with problem posing integ rated in introductory microeconomics theory, whether work? International Journal of Educational Research Review, 3 (4),1-10.

In Cycle 1 Lecturer management in implementing the Scientific Approach to the method Problem Posing already quite good. However, there are several steps that have lower grades than other stages, namely at the stage of doing Problem Posing and motivation End.

Phase commit Problem Posing have a low value because at the time Lecturer apply, lecturers are less able to make student active and enthusiastic in participating in learning, in addition to the student also looked confused, because the method of problem posing students were asked to create / submit about yourself and then answer it as well. While at the stage of final motivation Lecturers are also less able to motivate the students were confused when asked to create questions. This is because it is the students had never before had the name makes about themself. Most of them were only asked to solve problems or issues. Because of these shortcomings, the observer asks professors to be able to create an enthusiastic atmosphere for students to create questions.

Management Lecturer in implementing Problem Posing in cycle 2 has also been quite good. Reflection conducted in cycle 1 is Lecturers must fix phase commit Problem Posing and perform final motivation. If in cycle 1 Lecturer simply ask students to create questions about the counting function of demand, then in cycle 2 Lecturer fix it by asking students to create questions and its deals with the curve function and application of his theory on everyday life. As a result students become more active and enthusiastic. Unfortunately, in the previous stage Lecturer less good at doing apperception. Lecture submit request for sample calculation functions and not to review the theory of demand, so that the students also seem awkward.

Besides apperception, deficiencies in cycle 2 are also located on the stage watching. Lecturers also impressed hastein presenting the theory of supply as well as the law of supply for lecturers assume that the theory is almost equal to the demand as an example of the law of demand that has properties inversely while the laws of supply has the properties directly proportional. While, Lecture cite it not in real life because it considers the demand theory has been exemplified in real life as it has done in cycle 1.

To the observer asks Lecturer for another boost when applying the method of Problem Posing and advised not to rush in presenting the material. While on the other stages observer said it was good.

After reflection, then in cycle 3 Lecturer to motivate students so active at this stage by giving points to Students ask and answer questions from lecturers as well as calm and in no hurry to do apperception and delivering the material. Management Lecturer in applying the Scientific Approach to the method Problem Posing in cycle 3 to be increased to well categorized once and have met the success indicators of research so that the cycle was stopped at 3 cycles.

This proves that the results of this study support the theory of Johnson (2006) as saying that "Master CTL quality allows students to not only be able to reach the standards of academic values nationally, but also gain the knowledge and skills essential for learning throughout their lives". Of the phrase "Master CTL quality" means in applying learning approaches Lecturers must master all stages in approach Scientific method Problem Posing, because the activity Lecturer in applying Approach Scientific method Problem Posing already categorized very well, the lecturer can be said lecturer qualified as stated Johnson.

In addition to supporting the theory, the results of this study also supports research conducted by Rustini (2013) who said that with the implementation problem posing the teacher activity can increase. While this research activity has increased during the implementation of the method Scientific Approach Problem Posing is a lecturer activity.

This study is also consistent with the results of research Bungai (2006) which states that teachers who work in schools that have a positive climate shows that confidence in the effectiveness of school than their colleagues who work in a school environment less conducive. Scientific approach and methods with Problem Posing, then the college climate will increase and learning in the classroom will be more conducive and will have an impact on improving the Activities Lecturer.

Student activity assessment is taken from the stages in the implementation of Scientific Approach to the method of Problem Posing. Due Scientific Approach implemented by the method of Problem Posing the aspects being assessed on Student activity developed into 12 aspects. 
Prakoso,A.F., Fitrayati,D., Dewi,R.M. (2018). Scientific approach with problem posing integ rated in introductory microeconomics theory, whether work? International Journal of Educational Research Review, 3 (4),1-10.

Student activity results in cycle 1 classified as active. This is because most students do not know for sure about the method Scientific Approach Problem Posing, so students look confused as they used to get direct instructional model.

The lowest value of student activity in the first cycle lies in apperception stage, ask, Testing / demonstrating combined with the method Problem Posing, Communicating combined with the method Problem Posing, and the motivation End. A large part of students embarrassed to speak his mind so that the classroom atmosphere was quiet. This is because students are still adjusting to the Scientific Approach to the method Problem Posing they have never got before.

The most striking phenomenon is on the application of problem posing. Students impressed shocked when the lecturer asks them to create questions in groups. After making their questions were also asked to answer the questions that they have made. Students feel strange, because during the lectures they have not been asked to make the matter.

In cycle 2, students already feel able to adjust to the Scientific Approach to the method of Problem Posing although not fully. This is evidenced by the increase in value of the activity Students in cycle 2. On the other hand students are less enthusiastic when apperception stage and observed and the observer gives the low est value at this stage. At this stage of apperception and observe this done before the implementation of the method of problem posing which at that stage was still less able students remember the material in cycle 1 that the material demand. Students will not fully remember the demand curve although they could count function.

After Lecturers implement reflection and motivating form of additional values or points for every student who wants to ask or answer questions from lecturers and students more active in the discussion when the implementation of the method of problem posing it in cycle 3 student activity value increased to very active criteria. So, the cycle is stopped in cycle 3 because it has met the success criteria of the study.

Thus the results of this study support Salemi (2005) in his research that says that "Subject to the use of economic ideas to gain important insights into the issues and problems are interesting and relevant is a powerful motivator. This subject can attract students to make them more enthusiastic in learning economy ". The word "more enthusiastic" is a manifestation of the increased activity of the students in this study.

In addition to supporting the theory, the results of this study also supports some of the results of such research at the research Fauziah et al. (2013); Haji (2011); Rustini (2013) who said that with the implementation approach Scientific and methods Problem Posing the activity students will be increased.

Other research results as research conducted by Masitoh (2006) which states that in the opinion of student learning activities and respond to the opinions of others also an increase in each cycle when applying learning Investigation Group. With the discussion as well as the method of Problem Posing performed in this study will have a positive impact on improving students' learning activities business education class "A".

In terms of completeness study, the test used to determine the level of student mastery of the material to a lecture. Completeness in terms of learning outcomes per individual referred to by the thoroughness of the individual while the overall completeness of Students called the classical completeness. The instrument used to determine student learning outcomes are 45 multiple choice questions, with each cycle consisting of 15 questions.

In the analysis of the results of study showed an increase in classical completeness of students in each cycle is equal to $61.7 \%$ in cycle 1, cycle 2 and cycle 73.5\% 82.3\% 3 number. In the first cycle is known that the classical learning completeness students amounted to $61.7 \%$. This value has not met the success indicators of research that is equal to $80 \%$ of the lecturers and observers to reflect on the shortcomings that exist in cycle 1 . These deficiencies can be seen from the analysis of the activity of lecturers and students in cycle 1 who have low values at the implementation stage Problem Posing.

Most of the students have not been able to create questions about calculating the demand function. Having traced the cause is not yet conscientious student in calculating demand functions. The 
Prakoso,A.F., Fitrayati,D., Dewi,R.M. (2018). Scientific approach with problem posing integ rated in introductory microeconomics theory, whether work? International Journal of Educational Research Review, 3 (4),1-10.

formula and how to calculate it are correct, but they are less accurate in determining the multiplying and the positive or negative sign of coefficient demand function.

After post-test, most of the errors students answer lies in the indicator "function calculates demand and draw a demand curve". In calculating the already known cause is a lack of rigor student. While at the time of drawing curves derived from the demand function that they count also wrong because if the wrong arithmetic functions that they will result in an error then make a curve as both a linkage.

Cycle 2 shows the progress of classical learning completeness students. In post-test cycle 2 student of classical learning completeness of $73.5 \%$. Although it has not met the success indicators of research that is equal to $80 \%$, but the student's understanding of the Scientific Approach to the method Problem Posing already started to rise. In this cycle Lecturers make improvements at the stage of demonstrating that combined with problem posing stage is to demonstrate the calculation of the supply function. Lecture appoints one student to create questions and then ask other students to count them on the board. Lecture directing students to be more careful in determining the positive and negative signs as well as meticulous in multiplying and dividing numbers.

Once done post-test, student results on the indicator calculates the supply function has increased. However, the Rights Issue curve drawing indicator is still relatively low. This is because the students rush in determining multiple choices which they considered to be correct. In pure mathematical science, when drawing point coordinates, then the determination is $(x, y)$ and students get used to it because they got in junior high or high school. The introduction of microeconomic theory is not the case, but $(y, x)$ where $\mathrm{Y}$ is $\mathrm{P}$ (Price) while $\mathrm{X}$ is $\mathrm{Q}$ (Quantity). Students will often invert coordinates.

Finally in the third cycle of mastery learning classical Students reached $82.3 \%$, means that this value has met the success indicators of research that is equal to $80 \%$. Most of the students are also enthusiastic in participating in the learning process in every aspect although still there are students who did not complete due to the student have the ability under the other students.

Reflection has been done on this third cycle focused on indicators of market equilibrium curve drawing. Lecturers also provides guided demonstrations to students in order to draw the coordinates of the curve is not inverted and is consistent with points $(\mathrm{P}, \mathrm{Q})$

Thus, this study supports the theory Varelas and Ford (2008) which says that the approach is scientifically allow s teachers or curriculum developers to improve the learning process, namely by breaking the process down into steps or stages in detail which contains instructions for the students carry out learning activities, With elaborate stages contained on a scientific approach, students will feel guided and directed manner in accordance with the order so that students have an understanding of the process of calculating a function of demand, supply and price balance and describe the curve correctly.

This opinion is also supported by the Salemi (2005) in which he w rote that the study shows "we change instructors and lecturers who originally memorizing be applying economics to solve significant problems and performed repeatedly. By memorizing the student will be quickly forgotten, whereas by applying economics to solve the problem would be to make students into "economic literacy". By becoming "economic literacy, the student will achieve a lasting understanding and then make the results of student learning is enhanced. With the make and finishing matter is also a student activity that is done repeatedly, so will be able to improve student results. In addition to supporting the theory, this study also supports several studies, among research Fauziah et al. (2013); Haji (2011); Heraw ati, Siroj, and Basir (2010); Hidayati and Endryansyah (2014); Rustini (2013).

Moreover, this research is also supported by the results of Japa (2014) stated that compared to conventional learning models, learning models of quantum oriented on solving open issues in mathematics will produce outcomes that better thinking skills base, thinking skills critical and creative thinking skills of students. In this study were also given the atmosphere of learning problem, but the difference that makes the problem is the students themselves and they alone solve them so as to improve the understanding and of course the results of student learning business education class " $\mathrm{A}$ ". 
Prakoso,A.F., Fitrayati,D., Dewi,R.M. (2018). Scientific approach with problem posing integ rated in introductory microeconomics theory, whether work? International Journal of Educational Research Review, 3 (4),1-10.

Similarly, research conducted by Lamba,(2006) says that the results of the analysis and hypothesis testing that has been done shows that there are differences in the acquisition of significant physics learning outcomes between cooperative learning with classical learning methods. The study also alter the conventional learning model that originally form the Scientific Approach combined well with Problem Posing method that can ultimately improve student results in business education class " $\mathrm{A}$ ".

The findings relating to learning outcomes when implementation approach Scientific method Problem Posing namely the method of problem posing, students were asked to create a problem, if we want to make about it indirectly we were required to find an answer because if it can-not answer the question is not can matter. By thinking about the answer to that made by the students, the students will think twice. With twice the thinking process will increase student understanding more and positive impact on increasing student learning outcomes.

In addition to the findings of the problem posing method is also supported by the finding that of the scientific approach. Besides students experience the process of thinking twice, to create questions and make the answers, students are also guided by the scientific approach designed stages in detail. So that students acquire knowledge transfer bit by few accordance with the order, ranging from observing to make netw orking. Because of detailed stages, students will have a detailed understanding of the material anyway, so the results of student learning have increased.

From both of these findings, it is a blend of scientific approach to problem posing method can work very well because it can improve low student results to be better.

With the implementation approach of the scientific method problem posing, students as if the experience of learning in the real world (approach scientific) and when asked to make about them into thinking twice because it also had to think about the answer (method of problem posing), so that the memory of students become stronger. Robust memory of students will have a positive impact on improving learning outcomes, so the integrated of scientific approach to problem posing method works very well in improving student learning outcomes. It also good implementing these method on sport science and another social science, but the lecturer should be good on monitoring it. The suggestions, the lecturer should try again to combine the scientific approach or method Problem Posing with other learning models appropriate to the material they teach that student results improved further.

\section{REFERENCES}

Bahçuvanoğlu, F. F. (2018). Evaluation of teachers views concerning ideality levels. International Journal of Educational Research Review, 3(1), 21-27.

Bradshaw, Z., \& Hazell, A. (2017). Developing problem-solving skills in mathematics: a lesson study. International Journal for Lesson and Learning Studies, 6(1), 32-44. https://doi.org/10.1108/IJLLS-09-20160032

Bungai, J. (2006). Pengaruh Kompetensi Kepala Sekolah, Iklim Sekolah, dan Keefektifan Mengajar terhadap Prestasi Lulusan SMA. Jurnal Ilmu Pendidikan, 13(2), 91-99.

Culture, M. of E. and. Module Implementation Training Curriculum Guidelines 2013 (2013). Indonesia: Human Resources Development Agency of Education and Culture and Education Quality Assurance.

Fauziah, R., Abdullah, A. G., \& Hakim, D. L. (2013). Pembelajaran Saintifik Elektronika Dasar Berorientasi Pembelajaran Berbasis Masalah. Invotec, 9(2), 165-178.

Haji, S. (2011). Pendekatan Problem Posing dalam Pembelajaran Matematika di Sekolah Dasar. Jurnal Kependidikan Triadik, 14(1), 55-63.

Herawati, oktiana dwi putra, Siroj, R., \& Basir, dan H. . D. (2010). Pengaruh Pembelajaran Problem Posing terhadap Kemampuan Pemahaman Konsep Matematika Siswa Kelas XI IPA SMA Negeri 6 Palembang. Jurnal Pendidikan Matematika, 4(1), 70-80. 
Prakoso,A.F., Fitrayati,D., Dewi,R.M. (2018). Scientific approach with problem posing integ rated in introductory microeconomics theory, whether work? International Journal of Educational Research Review, 3 (4),1-10.

Hidayati, N., \& Endryansyah. (2014). Pengaruh Penggunaan Pendekatan Ilmiah (Scientific Approach) dalam Pembelajaran terhadap Hasil Belajar Siswa Kelas XII TITL 1 SMK Negeri 7 Surabaya pada Standar Kompetensi Mengoperasikan Sistem Kendali Elektromagnetik. Jurnal Pendidikan Teknik Elektro, 3(2), 2529.

Hodson, D. (1996). Laboratory work as the scientific method: Three Decades of confusion and distortion. Journal of Curriculum Studies, 28(2), 115-135.

Holmqvist, M. (2017). Models for collaborative professional development for teachers in Mathematics. International Journal for Lesson and Learning Studies, 6(3), IJLLS-12-2016-0051. https://doi.org/10.1108/IJLLS-12-2016-0051

Japa, I. G. N. (2014). Pengaruh Pembelajaran Kuantum Berorientasi Pemecahan Masalah dalam Pembelajaran Matematika terhadap Penalaran Mahasiswa. Jurnal Ilmu Pendidikan, 20(1), 9-16.

Johnson, E. B. (2006). Contextual Teaching Learning. Bandung: MLC.

Lamba, H. A. (2006). Pengaruh Pembelajaran Kooperatif Model STAD dan Gaya Kognitif terhadap Hasil Belajar Fisika Sisw a SMA. Jurnal Ilmu Pendidikan, 13(2), 100-107.

Lee, Y. C., Lau, K., \& Yip, V. W. Y. (2016). Blended learning for building student-teachers' capacity to learn and teach science-related interdisciplinary subjects. Asian Association of Open Universities Journal, 11(2), 166-181. https://doi.org/10.1108/AAOUJ-09-2016-0029

Masitoh, S. (2006). Peningkatan Aktivitas Belajar dengan Pembelajaran Investigasi Kelompok dalam Kuliah Metode Penelitian PLB II. Jurnal Ilmu Pendidikan, 13(2), 100-107.

Oladele, B. (2017). Analysis of 2014 Post UTME Score of Candidates in the University of Ibadan with Two Methods of Standard Setting to Set Cut Off Points. International Journal of Educational Research Review, 2(2), 44-51.

Riduw an. (2009). Learning Easy Research for Teachers, Employees and Researcher Starter. Bandung: Alfabeta.

Ristanto, R. H., Zubaidah, S., Amin, M., \& Rohman, F. (2018). The Potential of Cooperative Integrated Reading and Composition in Biology Learning at Higher Education. Int Ernational Journal of Educational Research Review, 3(1), 50-56.

Rudolph, J. (2005). Epistemology for the masses: The origins of the scientific method in American schools. History of Education Quarterly, 45, 341-376.

Rustini, Y. (2013). Pemahaman Konsep Pendapatan Nasional melalui Pembelajaran Langsung dengan Pendekatan Problem Posing di SMA Negeri 1 Tarakan. Jurnal Pendidikan Ekonomi, 6(1), 12-26.

Salemi, M. K. (2005). Teaching Economic Literacy: Why, What, and How. International Review of Economic Edcation, 4(2), 46-57.

Skott, C. K., \& Møller, H. (2017). The individual teacher in lesson study collaboration. International Journal for Lesson and Learning Studies, 6(3), IJLLS-10-2016-0041.https://doi.org/10.1108/IJLLS-10-2016-0041

Thobroni, M., \& Mustofa, A. (2012). Belajar dan Pembelajaran. Yogyakarta: AR-Ruzz Media.

Varelas, M., \& Ford, M. (2008). The scientific method and scientific inquiry: tensions in teaching and learning. USA: Wiley InterScience.

Wood, K. (2017). Teacher learning through collaboration. International Journal for Lesson and Learning Studies, 6(3), IJLLS 05-2017-0025. https://doi.org/10.1108/IJLLS-05-2017-0025 